\title{
Initiating Brunei Cross-Border Tourism (BCBT) as a Gateway to Borneo
}

Yabit Alas, Universiti Brunei Darussalam, Brunei

Muhammad Anshari, Universiti Brunei Darussalam, Brunei \& Universitas Islam Negeri Sunan Kalijaga, Yogyakarta, Indonesia

iD https://orcid.org/0000-0002-8160-6682

\begin{abstract}
Borneo is the third-largest island in the world, sharing three countries: Indonesia, Malaysia, and Brunei Darussalam. There is rarely research conducted for cross-border tourism (CBT) in Borneo. The study examines tourism development in Borneo then assesses potentials and challenges associated with Brunei-CBT as gateway to tourism in Borneo. A qualitative approach has been deployed focusing on advantages and challenges associated with Brunei as gateway for CBT in the Borneo Island. The analysis has shown that there is great potential in CBT for mobility and connectivity of people, goods, and services in Brunei-CBT's initiative. Brunei-CBT (BCBT) will trigger Brunei's economic shifting from an oil-based country to a service-based economy. Identified challenges mainly concern political support and willingness among participating countries, which may lead to barriers for connecting Borneo through CBT development.
\end{abstract}

\section{KEYWORDS}

Borneo, Brunei, Cross-Border Tourism (CBT), Kalimantan, Sabah, Sarawak, Tourism

\section{INTRODUCTION}

Borneo island is located at southeast of the Malay Peninsula and southwest of the Philippines. It is divided into four political regions; Kalimantan belongs to Indonesia, Sabah and Sarawak are part of Malaysia, and a remaining region comprises Brunei Darussalam (PBS, 1998). Cross border areas between three countries can contribute to economic development especially tourism industries across the borders. Borneo is the third largest island in the world primarily mountainous with dense areas of rain forest covering an area of roughly 287,000 square miles.

Borneo Island is niche area with enormous potential ranging from high-level interdisciplinary and multidisciplinary research to multi diversities of eco-tourism attractiveness. The tourism industry has experienced a steady growth over the decades and become one of the fastest growing economic sectors in the world (UNWTO, 2015). In fact, 2017 was another record year for the travel industry with international tourist numbers increasing by 6.8 per cent globally, the highest rate since the 2009 global economic crisis and well above UNWTO's long-term forecast of 3.8 percent per year in 2010-2020. 
There are problems with the current tourism practices in the Borneo without CBT that make Borneo becomes less attractive spot to visit. Those problems are complexities arrangement to move from one country to another, few packages tourism for the whole Borneo tourism program making it costly, without CBT the tourism in Borneo is inefficient and less attractive. The aim of the study is to portray current tourism's landscape for each country within Borneo Island then examine the potentials for Brunei-CBT (BCBT) initiative as the gateway for its development. Since there is no such CBT's studies for in the Borneo, this study will contribute to the body of knowledge as well as potentially applicable and practicable in the future of Brunei-CBT in Borneo. The research focuses on the potentials and challenges associated with Brunei-CBT initiatives in the Borneo's border areas.

\section{Cross Border Tourism (CBT)}

Tourism industries can directly affect much to the country development economically and socially development. Some of the impacts are opening it up for business, trade and capital investment, creating jobs and entrepreneurialism for the workforce and protecting heritage and cultural values (Batala et al., 2017). It generated US\$7.6 trillion (10\% of global GDP) and 277 million jobs (WTTC, 201). There are many advantages related to joint CBT collaborations. These include joint infrastructural developments, strengthened regional identity and marketing, improved regional economy, and catalyst for innovation and knowledge transfer (Timothy et al., 2014; Weidenfeld, 2013).

According to Newman et al. (1998), there are 273 species and 20 subspecies of Dipterocarpaceae in this area. FAO (1981) described Borneo as an island covered by a continuous carpet of evergreen rain forest dissected by swirling brown rivers. The climate is humid, with a rainfall varying between 2000 and $4000 \mathrm{~mm} /$ year. Given the abundance of rainfall, it makes sense that Borneo's flora is among the most diverse in the world. Borneo has nearly 11,000 species of flowering plants, about a third of which are indigenous. Cross-border tourism development projects often encounter challenges of different character (Skäremo, 2016). These challenges tend to be associated with difficulties to establish cohesiveness due to different social, cultural, economic, political, and organizational systems in two or more adjacent countries (Timothy \& Tosun, 2003; Blasco et al., 2014; Prokkola et al., 2015).

In order to make CBT possible, there are some criteria for entering collaborating arrangements as proposed by Lynch (2011) as shown at Figure 2. Firstly, the competitive attainment of strategic objectives leading to synergy resulting from a combination of various resources. Instead of offering a single country package, it will be more interesting and marketable for potential tourists when they

Figure 1. Borneo Island (Source: Encyclopedia Britanica)

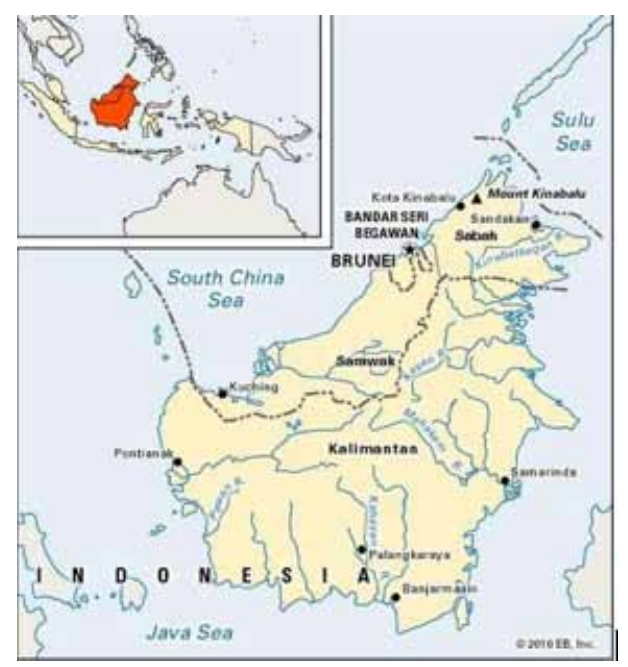




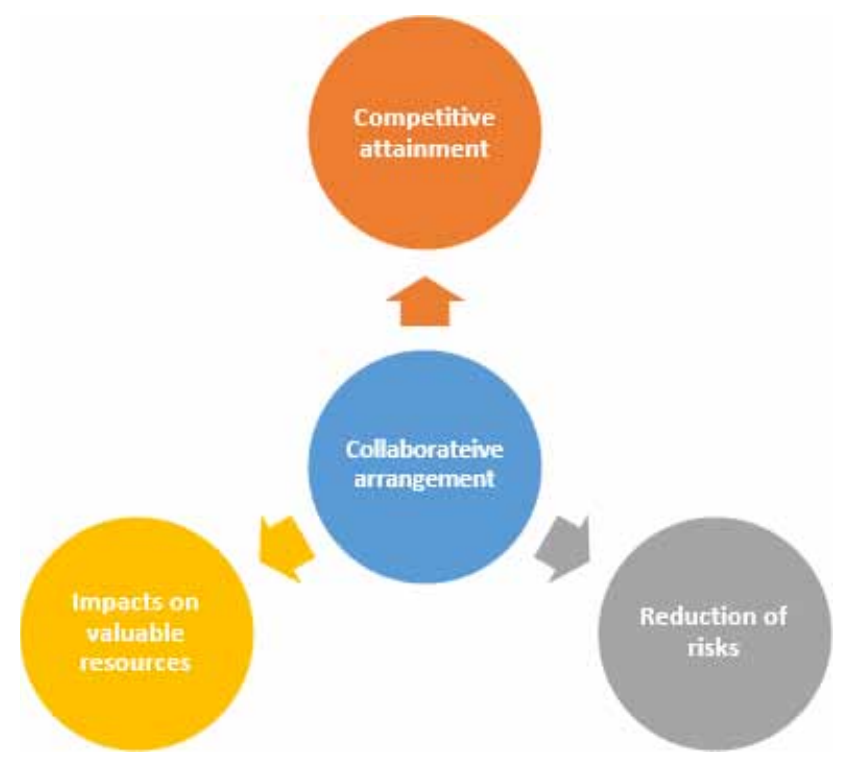

can visits three different countries with a single visa or a single tourism packages for all visits. In addition, the reduction of risk together with an increase in benefits means improving safety and removing barriers to support cross border tourism. Collaboration to create peace, safety and security across region will increase benefits for tourism in Borneo. Safety and security are the primary criteria for the selection of a tourism industry. Some barriers for CBT are complicated administration for people, goods, and transport movement across the border. It requires a hassle free administration.

\section{Brunei's Tourism}

Brunei is a sovereign nation on the island of Borneo surrounded by 2 distinct sections Malaysia and the South China Sea. Brunei is known for its beaches and biodiverse rainforest and majority of its forest are protected within reserves. The capital, Bandar Seri Begawan, is place the opulent Jame'Asr Hassanil Bolkiah mosque and its 29 golden domes (Wikipedia, 2018). Though, Brunei is a small country of 5769 square kilometers located on the northwest end of the island of Borneo. The population of Brunei is 415,717, with $76 \%$ in urban and $24 \%$ in rural areas, with an average growth of $2.2 \%$ per year. The population of Brunei Darussalam is $53 \%$ male and $47 \%$ female and is $73.8 \%$ Malay, $14.8 \%$ Chinese, and $11.4 \%$ other (AITI, 2010).

Brunei is fast emerging as a major tourism and hospitality destination that could soon overtake several developed markets. BRUNEI Darussalam scored the third fastest growth in tourist arrivals in Southeast Asia (SEA) last year, receiving some 259,000 international visitors. The figure is an 18.3 per cent increase from the previous year, according to the United Nations World Tourism Organization (UNWTO) in its report published this week (Othman, 2018).

Statistics provided by the Tourism Development Department show that the total number international tourists that arrived in the country through the Brunei International Airport (BIA) in the second quarter of 2017 reached 65,747 compared to 52,292 tourists in the same period last year, recording a 25.7 per cent year-on-year growth. The increase is mainly attributed to the consistently high travel demand from the main market areas since the first quarter of 2017 coupled with increased air connectivity due to chartered flights from the Far East market. Also contributing to the growth were the continuous increase in air connectivity by Royal Brunei Airlines (RB) and Lucky Air with the introduction of new services from South Korea and China, and the improved travel facilitation 
Table 1. Brunei Darussalam tourism statistics 2017 (Source: Borneobulletin, 2018)

\begin{tabular}{|l|l|l|}
\hline \multicolumn{1}{|c|}{ Purpose of Visit } & \multicolumn{1}{|c|}{$\mathbf{2 0 1 6}$ (Share \%) } & \multicolumn{1}{c|}{$\mathbf{2 0 1 7}($ Share \%) } \\
\hline Holiday & $93,544(42.8 \%)$ & $114,325(44.2 \%)$ \\
\hline Business & $37,339(17.1 \%)$ & $35,118(13.6 \%)$ \\
\hline Visit Friends and Relatives & $25,350(11.6 \%)$ & $26,742(10.3 \%)$ \\
\hline In Transit & $23,394(10.7 \%)$ & $23,199(8.9 \%)$ \\
\hline Government & $6,468(2.9 \%)$ & $6,426(2.5 \%)$ \\
\hline Exhibition & $1,340(0.6 \%)$ & $1,651(0.6 \%)$ \\
\hline Others & $24,146(11.0 \%)$ & $25,682(9.9 \%)$ \\
\hline Not Specified & $7,228(3.3 \%)$ & $25,812(10.0 \%)$ \\
\hline & & $\mathbf{2 0 1 7}($ Share \%) \\
\hline China & $\mathbf{2 0 1 6}($ Share \%) & $44,768(39.2 \%)$ \\
\hline Malaysia & $36,511(39.0 \%)$ & $17,950(15.7 \%)$ \\
\hline Philippines & $16,436(17.6 \%)$ & $7,949(7.0 \%)$ \\
\hline Indonesia & $5,220(5.6 \%)$ & $5,629(4.9 \%)$ \\
\hline Singapore & $4,417(4.7 \%)$ & $3,681(3.2 \%)$ \\
\hline
\end{tabular}

such as visa on arrival and multiple entry visa for the nationalities of China and Taiwan. While the Far East market continued to show persistent growth at 40.5 per cent, other markets like Australia, New Zealand and ASEAN have declined by 13.3 per cent, 8.4 per cent and 5.1 per cent respectively (Othman, 2018). In addition, Brunei was named the 13th best destination across the globe for Muslim travellers in the Organisation of Islamic Cooperation (OIC) countries at 2017 survey (Norjidi, 2018). In 2017, the total number of registered travel agents under the Tourism Development Department was 65 compared to 60 in 2016. All travel agents offer inbound and outbound activities.

\section{Malaysia (Sabah) Tourism}

Focusing on eco and rural tourism, Sabah is the second largest state in Malaysia and shares the island of Borneo with Sarawak, Brunei, and Indonesian Kalimantan. Sabah is richly blessed with nature diversity, unique cultures, fun adventure, beautiful beaches, and fantastic cuisines for the adventurous taste buds, the world's largest flower - the Rafflesia, and one of the highest mountains in South East Asia - Mount Kinabalu. Presently Sabah enjoys almost 100 direct international flights that connects the State to major airports in Kuala Lumpur, Seoul (Korea), Hong Kong and Shenzhen (China), Singapore, Jakarta (Indonesia) and Taipei (Taiwan), Clark and Manila (Philippines) and Bandar Seri Begawan (Brunei) (Sabahtourism, 2018).

Sabah achieves outstanding performance in tourism, with its rich natural environment and cultural diversity. In 2017, the tourist arrivals have increased reaching 3,684,734 with the revenue RM7.82 billion (NST, 2018). There are 12 foreign airlines flying to the Capital, Kota Kinabalu, on scheduled flights from 16 foreign destinations with total flight frequencies of 183 weekly. With additional 453 weekly domestic flight frequencies from outside Sabah, it has made Kota Kinabalu International Airport the second busiest airport in Malaysia after the Kuala Lumpur International Airport. The 630 hotels and 376 homestays in the state were insufficient to meet the growing demand for lodging.

Sabah Tourism Board (STB), which has embraced digitalization since 2009. STB began their online foray with Facebook and Twitter and now have an established presence on Instagram, YouTube, Weibo and WeChat, with the latter two specifically targeted at the Chinese market (Inus, 2018). 
Table 2. Sabah Tourism Jan - Aug, 2018 (Source: Sabahtourism, 2018)

\begin{tabular}{|l|c|}
\hline \multicolumn{1}{|c|}{ Country of Origin } & Statistic Value \\
\hline Asia & 831,887 \\
\hline Oceania & 16,734 \\
\hline Europe & 47,583 \\
\hline North America & 14,567 \\
\hline India & 3,763 \\
\hline Pakistan & 942 \\
\hline Middle East & 1,121 \\
\hline Others & 6,927 \\
\hline Malaysia & $1,638,684$ \\
\hline
\end{tabular}

Total visitors from China make up a third (33.2\%) of the overall share and followed by Korean with $17.9 \%$ in 2016.

\section{Malaysia (Sarawak) Tourism}

Sarawak, a Malaysian state on Borneo, stretches along the island's northwest coast, including many beaches on the South China Sea. It's known for the rugged, dense rainforest of its interior, much of it protected parkland. The capital, Kuching, is a bustling city set on the Sarawak River (Wikipedia, 2018). Sarawak has plenty to offer those seeking a slightly less conventional travel experience. With its lush rainforests, plentiful wildlife and diverse patchwork of ethnic groups, the state is positioning itself as a culture, adventure and nature (CAN) destination (Oxfordbusinessgroup, 2015). Sarawak saw 4.85 million visitors last year, bringing in tourism receipts of around RM8.59 billion. Top visitors to Sarawak came from China and Singapore, which saw rises in $20.2 \%$ and $15.8 \%$ respectively as of May this year (Tay, 2018). Sarawak's government has set aside RM12.5 million to bolster the state's tourist landscape. This is by utilising on emerging digital technology in the next three years. This also includes the redevelopment of the ministry's tourism web portal, augmented reality and virtual reality technology for tourism hot spots in the states, starting with the Old Kuching Heritage area (Tay, 2018).

\section{Indonesia (Kalimantan) Tourism}

Borneo is the third largest island in the world and $73 \%$ of Borneo is Kalimantan as a part of Indonesia while the remaining is made up of Malaysia and Brunei. Kalimantan is divided into four province; East Kalimantan, West Kalimantan, Central Kalimantan, North Kalimantan, and South Kalimantan (Table 3).

- West Kalimantan: There are some very beautiful and somewhat isolated beaches, while the coastline of Derawan Island is also special. Outdoor tourist attractions away from the beaches include mountain trekking, white-water rafting, river cruises, wildlife parks and national parks, where native orangutans can often be observed living in natural groups. A major attraction in West Kalimantan and the home of many thousands of wild orangutans. The Gunung Palung National Park comprises areas of completely untouched rainforest, although illegal logging is always an ongoing problem here (TravelSmart, 2016).

- East Kalimantan: Samarinda is capital of East Kalimantan, Samarinda lies on the far easterly side of Borneo, where is it just under $60 \mathrm{~km} / 37$ miles from the actual Makassar Strait. While, Balikpapan is a prominent seaport city with a population now approaching 800,000 residents, Balikpapan has gained much wealth from its timber production, oil fields and mining 
Table 3. Kalimantan Geography

\begin{tabular}{|l|l|l|l|l|l|}
\hline \multicolumn{1}{|c|}{ Province } & \multicolumn{1}{|c|}{ Area $\left.\mathbf{( k m}^{\mathbf{2}}\right)$} & \multicolumn{1}{|c|}{ Pop. (2010C) } & \multicolumn{1}{|c|}{$\begin{array}{c}\text { Pop. (2015C } \\
\text { prelim) }\end{array}$} & Pop. density/km ${ }^{2}$ & \multicolumn{1}{|c|}{$\begin{array}{c}\text { Provincial } \\
\text { capital }\end{array}$} \\
\hline Kalimantan Barat & $147,307.00$ & $4,393,239$ & $4,783,209$ & 32.5 & Pontianak \\
\hline Kalimantan Tengah & $153,564.50$ & $2,202,599$ & $2,490,178$ & 16.2 & Palangkaraya \\
\hline Kalimantan Selatan & $38,744.23$ & $3,626,119$ & $3,984,315$ & 102.8 & Banjarmasin \\
\hline Kalimantan Timur & 129,067 & $3,550,586$ & $3,422,676^{*}$ & 26.5 & Samarinda \\
\hline Kalimantan Utara & $71,176.72$ & 524,526 & 639,639 & 8.5 & Tanjung Selor \\
\hline Total & $544,150.07$ & $14,297,069$ & $15,320,017$ & 28 & - \\
\hline
\end{tabular}

Note: North Kalimantan split off East Kalimantan with resulting population and area loss for 2015 census.

(TravelSmart, 2016). There were 53,166 tourists entering East Kalimantan at 2016. The local Government targets the number of tourist visits especially divers expecting 300,000 people in 2018 with assumption each tourist spends 10 million Indonesian Rupiah (Budi, 2018).

- South Kalimantan: Banjarmasin is capita city of South Kalimantan. The city centred around the Sungai Martapura river, with a population now exceeding 800,000 people. Canal cruises, walking tours and the lively floating markets are amongst the main attractions in Banjarmasin, although it is the grand modern mosque known as the Mesjid Raya Sabilal Muhtadin that most people come to see, since it is Indonesia's second-biggest. Nearby, the long-tailed macaque monkeys on the Flower Island (Pulau Kembang) and the proboscis monkeys on the Surprised Island (Pulau Kaget) are just a boat trip away (TravelSmart, 2016).

- North Kalimantan: North Kalimantan borders the Malaysian states of Sabah to the north and Sarawak to the west, and by the Indonesian province of East Kalimantan to the south. It was the fastest growing province in the nation for 2015 census. Ethnicity in North Kalimantan consists of Dayaks and Javanese (predominantly), with a significant population of ethnic group of Tidung, Bulungan, Suluk, Banjarese, Murut, Lun Bawang / Lun Dayeh, and the other ethnic groups which is exist in the province.

- Central Kalimantan: Palangkaraya is the capital of Central Kalimantan and sited at the confluence of the Kayahan River and the Sabangau River. It is a medium-sized city, with a population just topping 200,000 people. There is an attractive peat swamp forest and rich in native Indonesian flora and fauna. Wildlife lovers will find more than 100 different special of mammals, 35 bird species and over 7,000 orangutans, which is amongst the largest concentration on Borneo (TravelSmart, 2016).

\section{METHODOLOGY}

This study developed on recent reviews of tourism in Borneo. Searches of Google Scholar and Scopus indexing journals and reliable online news were conducted to portray current development of tourism for each region. We chose English and Malay language as mostly spoken language in Borneo island articles published during the last five years. After removing duplicates and articles beyond the scope of this study, then it used thematic analysis of discussions that most importantly linked papers and articles to extract ideas and then applied them in reviewing potential of Cross Border Tourism in Borneo. Then, the analysis was developed to draw roadmap on the strategic thrust of Brunei as gateway for CBT in Borneo. 


\section{Mobility and Connectivity}

Tourism is one of the most promising sectors in the world and can offer different sets of tourism attractiveness across three states boundaries. The main objective for CBT in Borneo promotes mobility and connectivity of people within Borneo themselves. Lack of infrastructures development between cities in Borneo has become the main obstacle for mobility of people, goods and services. While, connectivity will trigger multi aspects development within the Island. The potential of CBT in Borneo is supported a steady political situations and similar socio-cultural cohesion increase the potential emergence of CBT development in Borneo. Currently, there are four points of entry for international tourists to Borneo's island. Those are Bandar Seri Begawan International Airport at Brunei Darussalam, Kota Kinabalu at Sabah Malaysia, Kuching at Sarawak for Malaysia, and Balikpapan International Airport at Indonesia (See Figure 3).

CBT in Borneo is highly demanded simply because it can offer one stop services for the whole tourism in Borneo. There are a lot of tourism spots those are unique and distinct only available at Borneo but the pivotal problems are complexities of administration and arrangement for tourists to reach the whole Borneo in package. Without CBT initiative, inbound and outbound tourism will not improve due to constraints of political administrations and infrastructure. Recent practice, when tourists plan to visit Borneo, they are normally just visited a single country then they have to arrange themselves if they plan to visit other countries in Borneo. CBT should consider for single tourism visa for any inbound or outbound tourists. It will improve mobility for people, goods, and services. The other problem of tourism without CBT in Borneo is cost uncertainty. For instance, when tourist come to Sabah and want to stop by at Brunei before going to Sarawak. They must arrange by their own for these travel. CBT should come up with the single package tourism across Borneo in order to attract more tourists coming. Bundling the tourism package will be easier when CBT initiative are implemented in Borneo. It will be definitely attract inbound tourists to come when their travel to Borneo is in package because it will provide them certainty in term of the budget and less difficulties during the visits. Furthermore, CBT will offer competitive value for each regions because the process of marketing can be made integrated marketing campaign. Meaning all the regions are partners in making CBT possible creating synergies and cooperation rather than competition.

However, one of the major impact from CBT in Borneo is boosting the economic development for the whole Island. CBT will promote ease of mobility and connectivity within Borneo that can create a single big of Borneo's market and production based on flow of people, goods, services and investment cultivating competitive economic advantages in the whole island, encouraging equitable economic development and integration into the region economy. CBT initiative in Borneo can be

Figure 3. Inbound and Outbound Route CBT in Borneo (Source: Authors' Comiplation, 2018)

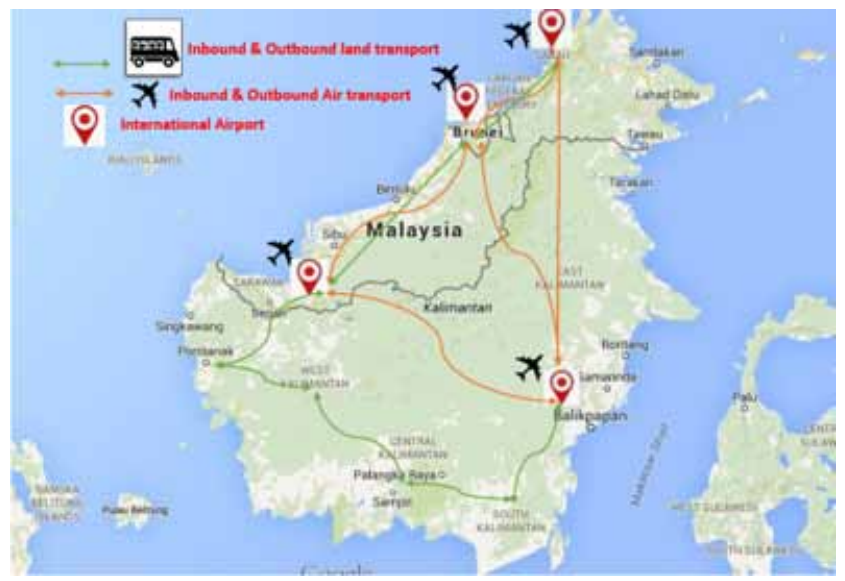


expected to close the development gap and strengthen the economic development within Borneo. Since, Brunei can become the main entrance for CBT in Borneo due to strategic geolocation and politics. Brunei has advantages to take the initiative of CBT in Borneo due to any decisions can be made within the country unlike the other regions like Sabah, Sarawak, and Kalimantan that might need central government consultative for CBT in Borneo. Therefore, Brunei may lead the initiative to make Brunei CBT (BCBT) is possible in Borneo.

\section{BCBT and Economic Transformation}

BCBT will trigger economical shifting from oil based country to service based economy. Developing a network of three countries in terms of services and infrastructures leading to economic development and the opportunities for all stakeholders to take part either public or private organizations and from Small Medium Enterprises (SMEs) to corporations. Some of the areas that will be massively developed from B-CBT initiatives are hospitality industries, infrastructure development, ICT development, and transport improvement (Figure 3).

Hospitality industries will create massive job opportunities for the following sectors; hotel and accommodation, recreation facilities, restaurants, souvenirs shops, travel operators, travel agents, and many more. Infrastructure development consists of physical development such as transportation route either land or air transport, hotels and accommodations, public services and amenities. In addition, inbound and outbound tourism lead to hard infrastructure development such as retails and stores, shopping centers, tourism facilities, education \& training centers, healthcare, health tourism, and Halal tourism center. Since infrastructure development will be costly then the initiative can be divided into different layers depending upon the complexities into the Government to Government (G2G), Business to Business (B2B) or People to People (P2P). For instance, G2G can facilitate Borneo information infrastructure and encourage e-commerce in Borneo.

Since Borneo is big island, BCBT should start offering low cost carriers flight (LCCF) connecting cities in the whole Borneo. LCCF will connect the cities in Borneo to support mobility of people, goods, and services. Furthermore, people mobility and information sharing within Borneo can contribute to other economic transformation of a knowledge-based economy. The knowledge-based economy relies on ICT development, community empowerment and collaboration, integration systems, and knowledge sharing as competitive advantages. LCCF will make the fare competitive because it will use the fare based on the distance not by region and it also considers the route between cities in Borneo as domestic flights not international.

BCBT initiatives will trigger the skills workers mobility. People will be exposed possibilities to understand the new roles in seeking opportunities to the broader market either within Borneo or incoming tourists. ICT infrastructure development will be heavily required in order to support knowledge based economy. BCBT will also triggers some industries to emerge such as creative industries, Financial Technologies (FinTech) or any disruptive innovation, digital marketplace's demands, SMEs development, techno-hub initiative, high-tech education's demand, and financial services. Finally, the main supporting components for BCBT are transportation development that will require a lot of job market creations. Some of those transport development are offering low cost carriers to the main cities within Borneo, aviation industry in general will improve, online transport for people and goods mobility, and cargo services.

The main challenges for BCBT is physical border arrangement, agreement, control and regulations among Indonesia, Malaysia, and Brunei. The agreement consists of movement of people, goods, and transports. A physical border can form a barrier to tourism flows, or it can be crossed almost unnoticed. Border permeability, the barrier effects caused by the border such as regulations for the movement of people and goods, will directly influence tourism flows and the development and distribution of tourism infrastructures in a border region (Prokkola, 2008). It requires high level agreement all countries within Borneo for shifting of the barrier-border to collaborative protected cross-border areas to support CBT. 
Figure 4. Projecting BCBT development (Source: Authors' compilation, 2018)

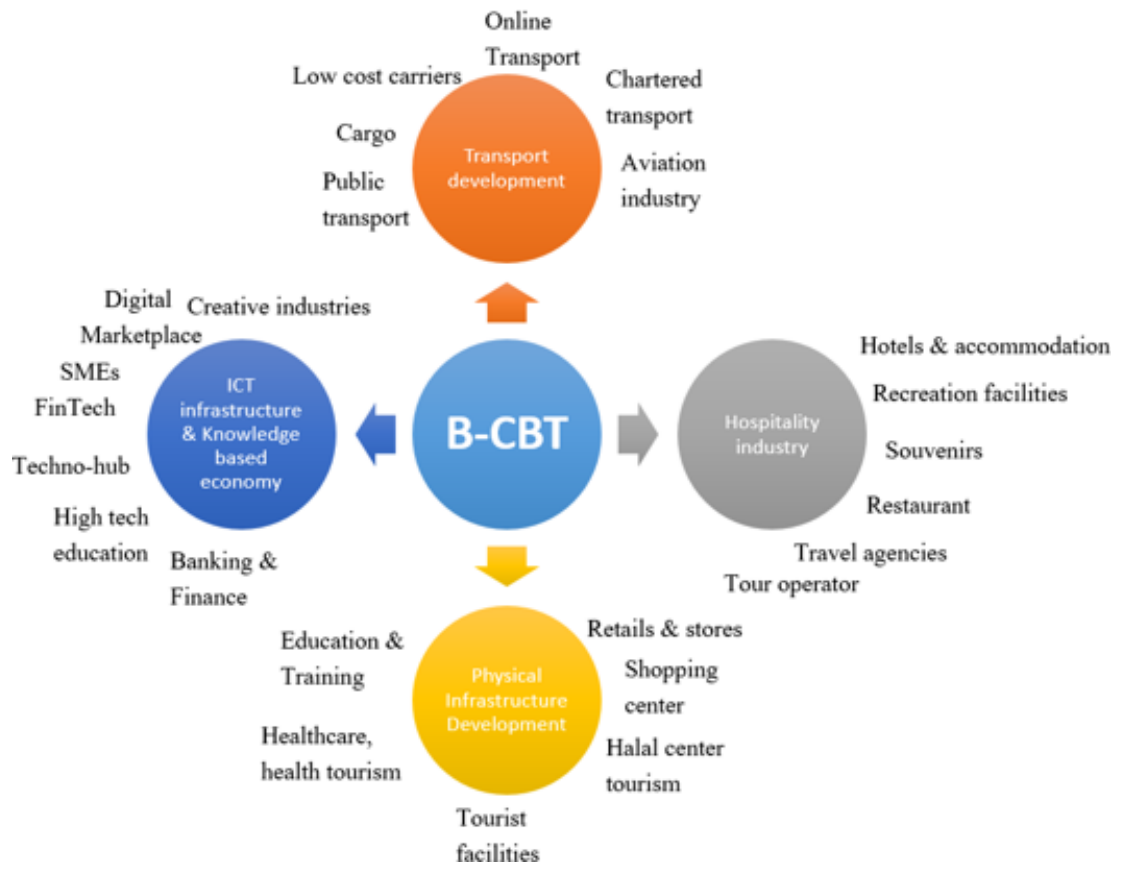

\section{CONCLUSION}

The study demonstrates a high potentials and possibilities to cooperate, Respondents perceive to increase their tourism offering as well as possibilities. Initiating CBT is complex tasks involves many parties from high level policies agreement between the countries to the technical of infrastructures development. The main challenge for Brunei as gateway for CBT is physical border arrangement, agreement, control and regulations among Indonesia, Malaysia, and Brunei. The agreement consists of movement of people, goods, and transports. It requires cooperation for the shifting barrier border that is relatively open but with considerable degree of border control security. While, Brunei-CBT (BCBT) can become the champion for the initiative due to strategic and supportive geographical condition. BCBT can trigger massive inbound and outbound tourism package because it can provide value added of one time service and one-time payment across Borneo. 


\section{REFERENCES}

AITI. (2010). Brunei Darussalam household ICT survey report 2010. Authority for Info-Communications Technology Industry of Brunei Darussalam.

Batala, L. K., Regmi, K., \& Sharma, G. (2017). Cross Border Co-Operation through Tourism Promotion \& Cultural Exchange: A Case Study along Nepal and China (T.A.R.) OBOR-Prospective. Open Journal of Business and Management, 5(01), 105-118. doi:10.4236/ojbm.2017.51010

Blasco, D., Guia, J., \& Prats, L. (2014). Emergence of governance in cross-border destinations. Annals of Tourism Research, 49, 159-173. doi:10.1016/j.annals.2014.09.002

Budi, K. (2018). Angkasa Pura 1 Efforts to Boost East Kalimantan Tourism. Retrieved 28 October 2018 from https://ekonomi.kompas.com/read/2018/03/05/170510226/upaya-angkasa-pura-1-dongkrak-pariwisatakalimantan-timur

Inus, K. (2018). Forget 'business as usual', Sabah tourism players told. Retrieved October 19, 2018 from https:// www.nst.com.my/news/nation/2018/01/328008/forget-business-usual-sabah-tourism-players-told\#cxrecs_s

Lynch, K., Berry, C., \& Sirey, J. (2011). A group-oriented inpatient CBT programme: A pilot study. Cognitive Behaviour Therapist, 4(1), 38-51. doi:10.1017/S1754470X10000152

Norjidi, D. (2018). Brunei a growing tourism destination. Retrieved October 20, 2018 from https://borneobulletin. com.bn/brunei-a-growing-tourism-destination/

NST. (2018). Tourism boom in Sabah. Retrieved October 19, 2018 from https://www.nst.com.my/news/ nation/2018/04/363647/tourism-boom-sabah

Othman, A. (2018). Brunei's tourist arrival growth is SEA's 3rd fastest. Retrieved October 20, 2018 from https:// borneobulletin.com.bn/bruneis-tourist-arrival-growth-is-seas-3rd-fastest/

Oxfordbusinessgroup. (2015). Sarawak's tourism strategy focuses on sustainable development. Retrieved October 19, 2018 from https://oxfordbusinessgroup.com/overview/sarawaks-tourism-strategy-focuses-sustainabledevelopment

PBS. (1998). Borneo: An Awesome Island. Retrieved 19 October, 2018 from https://www.pbs.org/edens/borneo/ awesome.html

Prokkola, E. K. (2008). Resources and barriers in tourism development: Cross-border cooperation, regionalization and destination building at the Finnish-Swedish border. Fennia, 186, 1.

Prokkola, E.-K., Zimmerbauer, K., \& Jakola, F. (2015). Performance of regional identity in the implementation of European cross-border initiatives. European Urban and Regional Studies, 22(1), 104-117. doi: $10.1177 / 0969776412465629$

Ratti, R. (1996). Problématique de la frontière et du développement des régions-frontières. Territoires frontaliers. Discontinuité et cohesion, Sciences de la Société $n^{\circ} 37$. Presses Univairsitaires du Mirail.

Sabahtourism. (2018). About Sabah. Retrieved October 19, 2019 from http://be.sabahtourism.com/

Skäremo, G. (2016). Cross-border tourism development: A case study of the Öresund Region. Academic Press.

Tay, V. (2018). Sarawak government pours RM12.5m into tourism sector. Retrieved October 19, 2018 from https://www.marketing-interactive.com/sarawak-government-pours-rm12-5m-into-tourism-sector/

Timothy, D. (2001). Tourism and political boundaries. Routledge.

Timothy, D. J., Guia, J., \& Berthet, N. (2014). Tourism as a catalyst for changing boundaries and territorial sovereignty at an international border. Current Issues in Tourism, 17(1), 21-27. doi:10.1080/13683500.2012. 712098

Timothy, D. J., \& Tosun, C. (2003). Tourists' perceptions of the Canada - USA border as a barrier to tourism at the International Peace Garden. Tourism Management, 24(4), 411-421. doi:10.1016/S0261-5177(02)00113-9 
TravelSmart. (2016). Kalimantan Tourist Attractions and Sightseeing. Retrieved 27 October 2018 from http:// www.world-guides.com/asia/indonesia/kalimantan/kalimantan_attractions.html

UNWTO. (2015). Why tourism? Retrieved October 20, 2018 from http://www2.unwto.org/content/why-tourism

Weidenfeld, A. (2013). Tourism and Cross Border Regional Innovation Systems. Annals of Tourism Research, 42, 191-213. doi:10.1016/j.annals.2013.01.003

Więckowski, M. (2013). Eco-frontier in the mountainous borderlands of Central Europe. The case of Polish border parks. Journal of Alpine Research, 101(2), 1-13.

WWTC - World Travel \& Tourism Council. (2015). Travel \& Tourism: Economic Impact 2015 Nepal. https:// sp.wttc.org/-/media/files/reports/economic-impact-research/countries-2015/nepal2015.pdf

Yabit Alas earned a PhD in Linguistics from the National University of Malaysia in 2004. The author's area of interest expanded not only in Linguistics but include culture, tourism, social works, and lately on IT in education.

Muhammad Anshari is researcher and academic staff at School of Business \& Economics, Universiti Brunei Darussalam. His professional experience started when he was IT Business Analyst at Astra International. Research Fellowship from The Government Republic of China (Taiwan) at National Taiwan University (Jan-Dec 2014). Research Fellowship from King Saud University - the Kingdom of Saudi Arabia 2009. 